\title{
THE USE OF CODE MIXING BETWEEN INDONESIAN AND ENGLISH IN INDONESIAN ADVERTISEMENT OF GADIS
}

\section{YESSY MARZONA}

\author{
Volume 1 Nomor 1 \\ JILP \\ ISSN: 2581-0804 \\ E-ISSN: 2581-1819
}

ABSTRACT

\begin{abstract}
This tendency is noticed when people use many ways of language variations to communicate or express their thought, ideas, and feelings. One example of these variations is code mixing. Code mixing is insertion of a piece of word other than that of your language, and you have no specific purpose or intention when doing communication. Code mixing is different from borrowing. Code mixing usually happens while people communicate in oral or written and in informal situation. In the case of code mixing, people sometimes mix two languages, particularly between national and a foreign language like English. However, code mixing does not only exist between the languages, there
\end{abstract}

is also the mixing between national and regional languages. The researcher use GADIS to do this research. It was found that there were three forms of code mixing used in advertisement in GADIS. They were words, phrases and sentences which were put in the middle of the sentence of advertisements. Meanwhile, the use of code mixing in advertisements had many functions based on the purposes of communication, as we knew; advertisement was an advertiser's way to communicate to the consumer, reader in this case. So, in this research it was found that there were three functions of the use of code mixing. They were greeting, informing, and rejecting.

Keywords: code mixing, indonesian and english in indonesian, advertisement, gadis

\section{INTRODUCTION}

The tendency of people to change and to modify words or utterances in order to simplify or make new styles of language is one of phenomena in communication that can be found in the course of a single communication episode. This tendency is noticed when people use many ways of language variations to communicate or express their thought, ideas, and feelings. One example of these variations is code mixing. Code mixing is insertion of a piece of word other than that of your language, and you have no specific purpose or intention when doing that (en. Wikipedia.Org/ wiki/ code- mixing). Language can change while the speaker wants to change to be understood by hearer. He or she needs to change to simplify the conversation and wishes to change or create a new style. The writer comes to understanding that the insertion from one language to other will not change the meaning of the language. It is a common phenomenon in societies in which two or more languages are used.

Hence, code mixing is commonly found in bilingual and multilingual society. According to Bloomfield in Chaer and Agusta (1995:112), bilingualism is the condition that shows the ability of speaker to use two languages. The ability to speak in two languages results in code mixing event. Bilingual society mixes words, phrases, and clauses together from one language 
to another in one sentence.

Based on the writer's observation, nowadays, code mixing has characterized the language of advertisements. The use of code mixing in advertisements inspires people to use the language of advertisement in daily conversation because the society tends to imitate what they read or watch. Code mixing in advertisement is also used to attract the readers or hearers to buy the product through the language of advertisement.

Generally, some of advertisement's words are taken from words in daily conversations. Then, advertisers take and make it more interesting in order to persuade consumers. One way to make the words of advertisement more interesting is by using two languages together in one advertisement or drawing picture to support the language of advertisements.

Advertisements can be found in electronic media and printed media. And the media which frequently use bilingual language are that media that deal with especially teenagers like the magazine. Most magazines usually present advertisements containing code mixing inserting in Indonesian and English. For example, "ngertiin mood si dia? Kamulah jagonya!" and "hero terbaru sepeda motor Honda!"

The use of code mixing between Indonesian and English in advertisements is very interesting to be analyzed. One way to know code mixing is by doing the field study of the use of code mixing in the language of advertisement. Besides, English is very important right now, most people use English as communication tool. That is why advertisement can be used as the nature of study that can make English easier to understand. Based on the above explanation, the writer was interested in analyzing the use of code mixing between Indonesian and English in Indonesian advertisement of GADIS.

Bilingualism is the use of more than one language or dealing with the ability to communicate naturally and fluently in more than one language in all areas of life (www. Geocities.com/.../bilingualism.html). Aspects discussed in bilingualism include code switching, code mixing, and borrowing (en. Wikipedia.Org/ wiki/ code- switching). Code mixing is insertion of a piece of word other than that of your language, and you have no specific purpose or intention when doing that, code switching is alternation between languages during your speech with other bilingual person, and borrowing entails integration of the word or phrase from one language in the other.

The example of code mixing is "ngertiin mood si dia, kamulah jagonya". And the example of code switching like speaker A speak to speaker B about how to use washing machine by using English and then speaker B talk again to speaker $\mathrm{C}$ about the same problem, and it is happen in the same time and same situation. In addition, the example of borrowing is there is someone at the door, go and see what they want to do! The word they refer to him or her.

Studies of code mixing enhance our understanding of the nature, process, and constrains of language used and individual values, communicative strategies, language attitudes, and function within particular social cultural contexts (Jacobson, 1998). The use of code mixing has become specific habit since a long time ago. Indonesian society has mixed two languages between Indonesian and some regional languages in their daily conversation. On the other hand, there has also been code mixing between two regional languages such as, Sundanese and Minangkabaunese. It occurs because Indonesian is known as the country with multiethnic groups. There are so many ethnics group with different dialects and languages that enrich the Indonesian culture. Because of that, Indonesian frequently used code mixing in their conversation.

There is also code mixing between Indonesian and foreign language. The use of code mixing within foreign language occurs because Indonesian is a part of international population. They cooperate, work, talk, make a friend or marry people from other countries that have different language. Of course, to converse well, they mix Indonesian with foreign languages. Generally, Indonesian is mixed with English.

The use of code mixing between Indonesian and English is not only found in daily conversation but it can also occur in advertisements of the printed or the electronic media. One of the printed media that uses code mixing in advertising the product is magazine. According to Luna and Peracchio (2003), consumers' language attitudes are an important consideration when it comes to write advertisement. It means that even advertisement that is written in two languages can awaken such association and that the same slogan can result in different reactions depending on the language that draw the most attention. Interestingly, the 
language that draws the most attention is the one that is used less in advertisement.

There are three aspects of language in the context of bilingual community; they are code switching, code mixing, and borrowing. The writer chose code mixing because; first, code mixing is primarily applied in printed materials whereas code switching is need in spoken language. Second, borrowing is quite similarity with code mixing and it can be found in electronic media and printed media. In this research, the writer analyzed code mixing in printed media especially in advertisement in GADIS.

Based on the identification of the problem, the study focused primarily on the form and the function of code mixing in advertisements that were found in GADIS. The writer tried to follow Khan's form of code mixing and Nababan's function of code mixing. The researcher chose magazine based on the consideration that there are so many advertisements use code mixing in this magazine. The magazine is the favorite reading material for

\section{BILINGUALISMS}

Bilingualism is the ability to master two different languages. It is command if somebody learns two languages in the same situation perfectly because his parents use these languages daily (Alwasilah, 1985:128). Spolsky (1998:45) classifies bilingual as a person who has some functional ability in the second language. This may very strong command of both languages (sometimes called balanced bilingualism). According to Titone (1972) in Hamers and Blanc (2009), bilingualism is the individual's capacity to speak a second language while following the concepts and structures of that language rather than paraphrasing his or her mother tongue. Moreover, the speaker from bilingual society can have the same ability with a native speaker in mastering the second language.

Bilingualism appears because of many factors in society (Yusrusyana, 1984:15). The first factor is immigration that is caused by economy, education, politic, religion, natural disaster and transmigration. For example, Indonesian student studies in Singapore, he should use English to speak with foreign people there but they can speak Indonesian with their family in their house. Next nationalism teenager, and the writer too. Moreover, the sources of data were only five editions of GADIS that were published in the period of March to July 2009.

Based on the research questions above, the general purpose of this research is to analyze code mixing in advertisement of GADIS. And the specific of the purpose is to answer the two questions formulated above, namely to analyze the forms and the functions of code mixing in Indonesian advertisement of GADIS. Because of many varieties of language, the researcher hopes that by knowing the forms of code mixing and their functions in Indonesian advertisement, it will add the readers' knowledge of linguistics. Besides, it will also give any contribution to everyone who wants to analyze code mixing, particularly that found in advertisement.

In this chapter, the writer discusses the result of viewing opinion or theories explained by experts both from Indonesian and foreign countries. Among theories are sociolinguistics, bilingualism, code switching, borrowing, code mixing, and advertisement.

movement that can lead to a need of national language, which is used to unite all nations or as officials language in formal communication. Then, the spread of religion causes a speaker to learn another language because he/ she should read holy book and religious literature. These factors bring some effects in mastering the second language for bilingual people.

Besides, for getting the second language we distinguish between language acquisition in unison and in succession. Mc Lughin in Yusrusyana (1984:21) states that language acquisition in unison occurs to the children who learn two languages before the age of three years. Meanwhile, language acquisition in succession occurs to the children who learn the first language before the age of three years and the second after it. For Indonesian people we can say that we belong to language acquisition in succession. Of course, the language acquisition will influence a speaker while having communication and it can produce code switching or code mixing. In bilingualism, we see language alternation i.e. code switching, borrowing, and code mixing. 


\section{Borrowing}

Brice (2003:2) declares that "borrowing is a linguistic strategy employed by both bilingual and monolingual speaker". Borrowing entails integration of the word or phrase from one language in the other. The borrowed word or phrase becomes a part of the other language and is assimilated into the second language. They will take phonological and morphological

\section{2. $\quad$ Code Mixing}

Code mixing is different from borrowing. Code mixing usually happens while people communicate in oral or written and in informal situation. In the case of code mixing, people sometimes mix two languages, particularly between national and a foreign language like English. However, code mixing does not only exist between the languages, there is also the mixing between national and regional languages.

Code mixing is the mixing of word(s), phrase(s), or clause(s) from two languages within the same sentence and speech event. Code mixing occurs when a conversant uses two languages together to extent that he/ she changes from one language to the other in the course of single utterance (Wardhaugh, 1998:103). The case of code mixing usually occurs in informal and the same situation and in the middle of sentences. Chaer and Agusta (1995:151) say that there is a primary code or the base code that is used and has functions while another code in speech case is only the pieces without functioning as a code in code mixing. Thus, code mixing usually occurs because a speaker from certain social background tends to choose a code to say their will and only involves some of elements of sentence such as, word, phrase, or clause.

As one category of language alternation, Yu- chi- Huang (1991:1) says that the mixing of two languages happens when the speaker can not think of the words in the original language and for reasons of identity. It can be seen that code mixing happens because of the speaker, the form and the function of language that means the characteristics.

It can be noted that borrowing may occur in the speech of monolingual and bilingual, while code switching and code mixing occurs in the speech of bilingual, multilingual and also in the speech of monolingual. And borrowing words often follow the grammatical rules of the new host language (Brice, 2003:2).

speaker from certain social background and tends to choose certain forms of code mixing to support certain function. And, the choice of code mixing shows the social prestige and personal identification. Meanwhile, according to Wardhaugh (1986:103), code mixing occurs when the conversant use both languages together to the extent that they change from one language to the other in the course of a single utterance. It means that the conversant just change some of the elements in their utterance. Code mixing takes place without a change of topic and can involve various levels of language, e.g. morphology and lexical items.

The forms of code mixing are also stated by Haugen and Beardsmore in Khan (2003:2). They say that many studies show nouns mix easily from one language to others, meanwhile structures or functions of language are rather difficult to have code mixing. Then, the next elements of language that mix easily after noun are verb, adjective, adverbials, preposition and interjections. On the other hand, pronouns and articles cannot be mixed with other element of language.

From some theories above, code mixing can also be found in the language of advertisements. Code mixing of advertisement in the printed media or the electronic media is usually used to attract or persuade the readers or hearer. Thus, advertiser will use certain forms and functions to attract the attention of the readers. So, we can say code mixing in advertisement is a way to influence the reader to buy the product. 


\section{a. Form of Code Mixing}

The form of code mixing could be word, phrase, and sentence. Fasold (1989:80) states code mixing occurs when pieces of one language are used while a speaker is basically using another language. The pieces taken from another language are often words but they can also be phrases or sentences.

The writer says that code mixing occurs when someone mixes two or more languages in one situation. According to Siddiqi (1994), mixed code is widely used and it is not confined to any specific subject, setting, and role. It means we can use code mixing in various places depending on with whom we are talking.

The people mix Indonesian and English because they can not find the Indonesian word suitable with the advertiser's idea. The writer found the form of word based on the word classes such as noun, adjective, conjunction, and interjection.

\section{Word}

Richard (1985:331) defines that word is the smallest of the linguistic units that occur on its own in speech or writing. Word can be noun, verb, adjective, adverb, conjunction, and interjection.

1) Noun

Richard (1985:196) defines that noun is a word, which (a) can occur as the subject of a verb or the object (complement) of preposition (b) can be modified by an adjective and (c) can be used with determiners. Noun typically refers to people, animals' places, things or abstractions.

\section{Phrase}

Richard, (1985:218) states that a phrase is a group of word, which form a grammatical unit, a phrase does not contain an affirmative verb and does not a subject predicate structure. Phrase is a group of words functioning as a single unit in the syntax of a sentence (en. Wikipedia.Org/ wiki/ phrase). For example, the house at the end of the street is a phrase. It acts like a noun. It can further be broken down into two shorter phrases functioning as adjectives: at the end of the street, a shorter prepositional phrase within the longer prepositional phrase. At the end of the street could be replaced by an adjective such as nearby: the nearby by house or even the house nearby. The end of the street could also be replaces by another noun, such as the crossroads to produce the house at the crossroads.
2) Verb

The verb is perhaps the most important part of the sentence. A verb or compound verb asserts something about the subject of the sentence and express actions, events, or states of being. The verb or compound verb is the critical element of the predicate of a sentence.

\section{3) Adjective}

Richard (1985:5) states that an adjective is a word that describes the thing quality, stating or acting which a noun refers to. For example "black in a black hat" is an adjective.

\section{4) Conjunction}

Richard (1985:58) states that a word, which join words, phrase, or classes together, such as but, and, so, when. Units larger than single word which function as conjunction and sometime known as conjunctive, for example so that, as long as, as if.

\section{5) Adverb}

Richard (1985:6) states that a word that describes or adds to the meaning of a verb, an adjective, another adverb, or a sentence and which answer such as question as how?, where?, or when?. In English many adverb have a $l y$. For example adverb of manner is carefully, slowly, adverb of place here, there, locally. And adverb of time now, hourly, yesterday.

6) Interjection

Interjection is used to answer a question that is asked in Indonesian. But interjection is seldom used in advertisement. For example "kulit kering? Good bye dech!".

\subsection{Sentence}

Richard, (1985: 7) says that a letter or sound, or group of letter or sound, which is added to a word, and which changes the meaning of function of the word. Affixes are bound form that can be added (a) to the beginning of word (= a prefix), in English un- which usually changes the meaning of a word to its opposite: kinunkind. (b) to the end of word (= a suffix), in English- ness which usually changes an adjective into a noun: kind-kindness. (c) within a word (= an infix)

\section{Function of Code Mixing}

The function of code mixing used in advertisement can be divided into many categories such as for greeting, rejection, opinion, suggestion and emotional expression.

Greeting is often, but not always, used 
just prior to a conversation. For example say hello or hi when we meet someone in anyplace. Rejection is an interpersonal situation that occurs when a person or group of people exclude an individual from a social relationship, example say no to something when we don't want to do it. Opinion is a belief that may or may not be backed up with evidence, but which can not be provided with that evidence. Suggestion is giving some opinions to something. And emotional expression is observable verbal and non verbal behavior that communicates emotion, can occur with or without self- awareness.

According to Nababan (1984:32), the code mixing sometimes occurs when the speaker intends to show his educational status or his social class. Language mixing is also used to express emotion, close personal relationship, and solidarity. The example of express emotion is "ngertiin mood si dia? Kamulah jagonya!". Besides the example of close personal relationship is "hallo sobat setia GADIS!" And the example of solidarity is "sobat GADIS, menghormati people yang berbeda agama adalah salah satu tindakan positif in your life". In addition, Richard (1985:113) states that the purpose for which an utterance or unit of language is used, in language teaching function are often described as categories of behavior.

\section{b. Advertisements}

The source of information like newspapers, magazines, televisions, radios, internet, and others often certain advertisements that sells goods from advertiser. An advertisement is the art of persuasion. It tries to persuade the consumer to buy products that are offered. Noviani (2002:53) says that an advertisement tends to exaggerate something. So it does not reflect the truth. Marchand in Noviani (2002:54) states that advertisement is a hall of distorting the reality. And nowadays, most of products have been advertised in order to promote to public. For example, fashion, cosmetics, electronics, automotive, foods, educations and school.

According to Jefkins (1997:15), advertisement is the system of selling through spreading information. It is important to note that not all information can be included in advertisements but only one certain information is advertised. The British Institute of Advertising Practice defines advertising is the persuasive selling message that is directed to the potential candidate buyer at certain goods or services with cheaper cost. Then, Wolseley (1972:73) decides advertisement as a tool which is intended to create immediate sales and a climate favorable sale.

One printed media of advertisement that influences a buyer strongly is magazine because magazine is printed regularly, such as, daily or monthly, which always contains different advertisements in each edition and of course it can be found easily. Lately, advertising grows quickly with new language style that makes

advertising can be separated with linguisticts.

Wolseley (1972:78) classifies advertisement into two, display advertisement and classified advertisement. A display advertisement uses various sizes and faces of type and drawing or photograph as illustration and it may occupy any amount of space into one page or several dozen for a single advertiser. This type would be found in all commercial magazines or newspaper. Meanwhile, a classified advertisement is a small announcement, usually in a small type, arrange in special column under classification. Sometimes these types are called "wants advertisement" or "help wanted". The classified advertisement would be found in most of the business magazines.

Jeffkins (1997:390) gives seven categories of advertising. They are consumer advertising, business advertising, trade advertising, retail advertising (s), cooperative advertising, financial advertising, and recruitment advertising. Each of these categories needs a special treatment that is called "the heart of advertising" in creative appearance and media that are used.

To support the advertising, words, symbol, pictures and color are elements that make advertising different from the scientific words or linguistics because one advertisement has to convey the persuasive and strong selling messages. For making it, there is copywriting that means wring art of selling message. A copywriter should write messages that attract attention, interest, desire, conviction, and action. 


\section{METHOD}

After the data were collected, it was shown that GADIS has many advertisements which use code mixing insertion in English and Indonesian these advertisements were the persuasive advertisements. These advertisements used code mixing in order to market the product that made the reader read for looking a new thing through GADIS.

In this paper, it was found that there were three forms of code mixing used in advertisement in GADIS. They were words,

\section{a. The Form}

The forms that were used in code mixing in GADIS advertisements that are discussed below are words, phrases, and sentences.

3.1.1 Words

Most of advertisements used word in English that was mixed with Indonesian. Advertiser tends to put word in English in advertisements that were written in Indonesian. Some of pronunciations of these words were written in Indonesian pronunciation. Of course, the language of advertisement looked more interesting. The findings of this research showed that the use of words in advertisement was dominated with noun and adjective. But there were some advertisements that also used verb, conjunction, or interjection in English that were mixed with Indonesian.

\section{$1 . \quad$ Noun}

The use of noun that was written in English was mixed with Indonesian dominates the research. Many copy writers of advertisements chose to write noun in English then they made advertisement's language in Indonesian by putting some noun in English. (Conello walls)

1) Dapetin gadget seru buat gebet!

2) Jadilah tamu istimewa GADIS selama tiga hari! Kamu bisa room- in dirumah GADIS dan ikutan serunya bekerja sebagai jurnalis dan fashion stylist. (GADIS)

3) Dobraklah pemikiran bahwa kebaya adalah pakaian tua yang hilang tergerus zaman. Padankan dengan fearless T- shirt dan short pants jeans yang sensasional. Tambahkan scarf yang dijadikan obi? Avant-garde! (Souvenir shop)

2. Adjective

The use of adjective in English gives phrases and sentences which were put in the middle of the sentence of advertisements. Meanwhile, the use of code mixing in advertisements had many functions based on the purposes of communication, as we knew; advertisement was an advertiser's way to communicate to the consumer, reader in this case. So, in this research it was found that there were three functions of the use of code mixing. They were greeting, informing, and rejecting.

effect to the reader to buy the product. Thus, many advertisements used adjective in English to attract the reader attention, although the used of adjective in Indonesian were also found in advertisement that were written in Indonesian. The use of this form has relation to function of code mixing in advertisement that can be looked in the discussion of the function of code mixing in advertisement in the sub chapter.

4) Pasti bete banget kalau rambut patah- patah dan rontok. Nggak perlu panic, sekarang ada Dove yang bisa jadi solusi. Kali ini, Dove meluncurkan Dove Hair Fall Therapy System yang membantu menjaga kelangsungan "hidup" rambut kita. Ada tiga varian yang bisa kita pilih, yaitu shampoo, conditioner, dan leaveon serum, agar masalah rambut yang mulai patah- patah dan rontok, bisa langsung teratasi. Leave- on serum dari Dove ini, bisa memberikan perlindungan 10x lebih baik, menghaluskan rambut secara instant dan dirancang untuk tidak meninggalkan rasa lengket. (Dove hair fall)

5) Tiramisu ternyata bukan hanya lezat untuk dimakan, tapi juga bisa jadi ide kreatif untuk koleksi make up Caring Colours. Tiramisu Sensation merupakan rangkaian make up natural dan warm yang bisa menyempurnakan tampilan kamu. Jadi, classy, anggun dan vintage. Caring colours selalu menciptakan rangkaian make up yang teruji secara klinis, mampu melindungi wajah dari pengaruh buruk lingkungan. Jadi, keuntungannya dobel dech, bisa tampil cantik sekaligus sehat. (Caring color)

$$
\text { 3. Verb }
$$

Here, the verb that was written in English did not stand alone. Advertiser used affix of Indonesian that was mixed with English and sometime without mixing with affix. There were 7 items of substitution of verb when the 
researcher did the research. We saw this mixing in:

6) Tinggalkan segala sesuatu yang standard en mulailah melirik yang benar- benar beda. Misi pertama, lihatlah jari- jarimu yang sepi dan kembangkan inspirasi dengan cincincincin heboh ini. Bentuk, warna dan size- nya yang unik, sanggup bikin kamu jadi cewek yang stands out from the crowd! (koleksi: welcome, the anomalous ring!)

7) Simpan handphone kesayangan kamu di tempat yang lucu dan seru. Selain bisa menambah koleksi sarung handphone, juga bisa mempercantik handphone kamu lho. Kamu bisa hunting bareng teman se- geng di weekend ini. Pasti menyenangkan. Selamat mencari! (cover your phone)

8) Main tebak- tebakan, yuk! Kali ini kita akan bermain dengan alat musik. Tapi, bukan alat musik biasa lho. Soalnya, yang berikut ini adalah alat musik tradisional dari seluruh dunia. Apa saja sih alat musik unik ini! Baca dulu clue- nya lalu cocokkan dengan gambarnya. Selamat bermain! (kuis tebak alat musik)

\section{Conjunction}

Conjunction usually used in advertisement were and and so these conjunction were written in most of advertisements in GADIS. But, the advertisers in writing conjunction did some modifications. For example and was written in three form. They were and, en, or n'. The data of the used of conjunction in English in advertisements are:

9) Tinggalkan segala sesuatu yang standard en mulailah melirik yang benar- benar beda. Misi pertama, lihatlah jari- jarimu yang sepi dan kembangkan inspirasi dengan cincincincin heboh ini. Bentuk, warna dan size- nya yang unik, sanggup bikin kamu jadi cewek yang stands out from the crowd! (koleksi: welcome, the anomalous ring!)

10) Sensasi Lux memang lebih dari yang kamu bayangkan. So, jangan lewatkan LUX Foamphoria, semakin cantik setiap hari dengan Lux. (Lux Foamphoria)

\section{Interjection}

Besides, there was interjection that was also used in advertisement. Interjection was used to answer a question that was asked in Indonesian. The use of this form in English was more interesting that were question which was answered in Indonesian. However, interjection was seldom used in advertisement. The data that used this form can be seen below:

11) Banyak cara bermain dengan kemeja oversized. Buat detail dekonstruktif dengan volume longgarnya, padukan dengan legging, gulung lengannya, atau jadikan kemeja sebagai luaran. Whatever you choose? Day or night, mix $n$ ' match dengan kemeja longgar nggak akan ada habisnya! (mode: too big for me!)

\section{b. Phrases}

Phrase in English was seldom used in advertisement. But we can see some of them as icon of the product that was advertised. It usually stood alone and was continued with Indonesian in another sentence, some of phrase also were put in the middle of an Indonesian sentence.

12) Musik Hip- Hop mucul tahun 70- an di Bronx, New York City, merupakan gabungan rap dengan breakbeats yang biasa dimainkan di pesta- pesta antar blok di daerah Bronx. Everything bling- bling yang dipadukan dengan sportylook adalah key- element untuk bergaya hip- hop. Gold mini drapery dress ditumpuk dengan rok lipat ala cherrleader plus aksesoris serba emas, cukup mewakili gaya hidup Hip Hopers.( Mode: to the BEAT y'all!)

13) Pertemukanlah warna neon yang serba bright- light denganwarna khaki yang berunsur earth- dusty color. Apa yang akan kamu dapatkan? Tentu saja gaya serba keren dan berani. Cari dress yang menggabungkan kedua warna ini, atau bisa juga kamu gabungkan dengan aksen tumpuk. Kamu juga bisa tampil lucu dengan serba detail dan creative fabric dress. Tinggal pilih dan ikuti empat gaya keren ini.(Mode: mix the colors!)

14) Tas kotak transparan memang eyecatching banget. Bikin semua mata penasaran ingin melihat barang apa saja yang dibawa. (my lovely bag)

There are three form of code mixing; they are word, phrase, and sentence. But from the discussion above, the writer only found two forms of code mixing. They were word and phrase. Most of these forms appear in every advertisement in this magazine. 


\section{b. The Function}

After analyzing the data, the writer can describe functions of code mixing that occur in advertisement GADIS.

\subsubsection{Greeting}

The advertiser was using English language in starting sentence mixing with Indonesian language. But the writer didn't find the advertisement as greeting in GADIS.

\subsubsection{Informing}

Informing was used to give information for the reader about something in order to make the reader follow interesting product and buying the product. See the following example bellow:

15) Sensasi Lux memang lebih dari yang kamu bayangkan. So, jangan lewatkan LUX Foamphoria, semakin cantik setiap hari dengan Lux. (Lux Foamphoria.

16) Nama- nama yang digunakan sebagai istilah dalam kamus fashion, ternyata punya asal- usul yang seru lho. Misalnya, celana Bermuda, bikini, bahkan sepatu mary- jane yang sangat kita kenal, memiliki kisah perjalanan tersendiri. Now qils, let's the story begin....(info mode)

17) Nggak terasa, tren fall/ winter 2009 sudah mengintip dan menunggu gilirannya. $B e$ ready, girls! Ini dia tren beauty yang terinspirasi dari look yang ultra chic tapi tetap tough dengan sedikit rock n' roll twist. (Neo glam)

Advertiser used many ways to market the product that are advertised. One of these was shown by the data above. By using code mixing in informing what kind of product advertised, the advertiser hoped the reader to be interested to buy the product because some of Indonesian reader think that products advertised in two to language were sold internationally. So, the advertiser used this way to persuade the reader.

\subsubsection{Rejecting}

To refuse something, this expression had negative form. See the example below:

18) I () to make you smile ponsel cybershotTM C510 dengan teknologi smile shutterTM akan menangkap setiap senyuman secara otomatis. No senyum, no foto. (Sony Ericsson Cyber-shot).

From the data above, the advertiser mixed English into Indonesian. The word no was used in code mixing to show suggestion expression. The word "no" it means didn't do it.

Based on the discussion above, we can see three forms of code mixing used in advertisement. They were word, phrase, and sentence. Word dominates the finding of the form in this research. Besides, phrase and sentence followed words in the forms of code mixing in language of advertisement. These forms were like what has been stated by some researchers in chapter II. One of them was Khan who said that code mixing can consist of words, phrases, and sentences.

Word as one of forms of code mixing in this research consists of a noun, a verb, an adjective and a conjunction (Richard, et al). They were put in the middle of the sentence in the advertisement. But, the use of noun dominated the findings. While, conjunction that related words, phrases, or sentences in this research were found in the different forms in its writing. It can be seen from the writing of and. The copy writer wrote it such as and, n' or en. And interjection was used to answer advertisement that was making in the suggestion form.

The phrase in code mixing in advertisement usually showed the icon of the product but not all phrases showed it. Finally, sentence liked a phrase; sentence sometimes was used to show the icon. Sentences usually stood alone, not in the middle of the sentences of advertisement.

The next finding of the research was the function of code mixing. As stated by some expert in chapter II too. The function of code mixing was based on the purpose of the communication. In this research we saw three functions of the use of code mixing in advertisement. Generally, the researcher found that many advertisements used code mixing to show the superiority of the product than others

If we looked the field research that has been done by Khan, Nababan and Richard to the bilingual society, they concluded that code mixing usually occurred in informal situation and the function of the use of code mixing in this study was based on the purpose of conversation such as greeting, informing, and rejecting. In this research the researcher found that the purpose of the advertisement was to persuade and attract the reader to buy the product. The advertisers used English that was mixed with Indonesian because advertisers wanted the readers to feel the language of the advertisements were the same as the readers' language in daily conversation.

In conclusion, the use of code mixing in advertisement was a way to promote the product in order to make the reader believe and finally they bought the products. 


\section{DISCUSSION}

\section{a. Conclusion}

Based on the discussion of data in chapter IV, there were some conclusions that could be drawn. Firstly, it was found there were three forms of code mixing that were written in English used in advertisements written in Indonesian. Forms that were found in this research were words, phrases, and sentences. The words that were found could be substitution of noun, adjective, verb, conjunction, and interjection. Meanwhile, the phrase and the

\section{b. Suggestion}

There were so many advertisements in the printed media using the persuasive word to persuade the readers. The researcher suggested the reader to choose the product not only based on the language of advertisement but also the languages can influence the mind of the reader. Moreover, the researcher only observed the code sentence in code mixing were combined with Indonesian and put in the middle of some sentences of Indonesian advertisement.

Secondly, the function of code mixing in advertisement was to attract the readers' attention in order to persuade them to buy the product. In this research, we could see three functions of code mixing in advertisement found in GADIS. They were as greeting, informing, and rejection.

mixing in advertisement of magazine while there were many studies that could be done related to code mixing or the other language alternation for example code switching, and borrowing. Therefore, the researcher also suggested other researcher that might be interested in code mixing from other media to do the research. 


\section{Bibliography}

Alwasilah, A. Chaedar. 1985. Sosiologi Bahasa. Bandung: Penerbit Angkasa.

Brice, Alejandro. 2003. Code Switching: A Primer for Speech- Language Pathologists. Mankato State University, Retrieved on March 18, 2009 from www.Google.com.

Chaer, Abdul and Leonie Agusta. 1995. Sosiolinguistic Suatu Pengantar. Jakarta: PT. Rineka Cipta.

Crystal, David.1997. The Cambrige Encyclopedia of Language. New York: Cambridge University Press.

Fasold, Ralph. 1989. The Sociolinguistic of Society. New York: Basil Blackwell Inc.

Gay. 1987. Competences for Analysis and Application. London. Merril.

Gumperz, J. 1982, Conversational Code Switching. In J. Gumperz Discourse Strategies. Cambridge: Cambridge University Press.

Hamers, F. J \& Blanc, H.A.M. 1987. Bilinguality and Bilingualism. Cambridge: Cambridge University Press, Retrieved on February 16, 2009 from www.google.com.

Hoffman, C.1991, an Introduction to Bilingualism. London: Longman.

Holmes, Janet. 2001. An Introduction to Sociolinguistic. 2nd ed. Malaysia: British Library Cataloguing- in- Publication Data.

Hornby, A.S. 2002. Oxford Advanced Learner's Dictionary.London:Oxford University Press.

http://en.wikipedia.org/wiki/codeswitching, 2009

Jacobson. 1998. Meaning and Form in Code Switching. Berlin New York: Mouton de Gruyter, Retrieved on June 8, 2009 from www.educ.utas.edu.au/../ 21- 2.pdf.

Jefkins, Frank. 1997. Periklanan. $3^{\text {rd }}$ ed. Yati Sumiharti and Singgih Agung (editor). Jakarta: Erlangga.

Khan, Yahya. 2003. Alih Kode Dan Campur Kode Dalam Masyarakat Bilingual. Universitas Negri Semarang. Retrieved on March 18, 2009 from http://www.apfippsi.com/alihkode.html.

Luna, David and Laura Peracchio. 2003. Where there is A Will: Motivation as a Moderator of Language Processing by Bilingual Consumers Psychology and Marketing is (7- 8).
Retrieved on March 18, 2009 from www.google.com

Nababan, PWJ. 1984. Sosiolinguistik Suatu Pengantar. Jakarta: PT Gramedia

Nazir, Moh. 1988. Metode Penelitian. Jakarta: Ghalia Indonesia.

Noviani, Ratna. 2002. JalanTengah Memahami Iklan. Yogyakarta: Pustaka Pelajar.

Richard. 1985. Longman Dictionary of Applied a linguistic. Hongkong: Longman Group (FE) Ltd

Siddiqi, Mohammad. 1994. Hindustani English Code Mixing in Modern Literary. Retrieved on March 18, 2009 from www.google.com

Sudaryanto. 1998. Metode Linguistik. Yogyakarta: Gajah Mada University.

Suwito. 1983. Sosiolinguistik Teori dan Problema. Surakarta: Henary Offset.

Skiba, Richard. 1997. Code Switching as a Countenance of Language Interference. Retrieved on March 18, 2009 from www.google.com

Spolsky, B.1998.Sociolinguistics.

Oxford: Oxford University Press, Retrieved on

February 16, 2009 from www.google.com.

Victoria, F and Rodman R. 1998. An Introduction to Language ( $6^{\text {th }}$ edition). Fort Worth. TX: Harcourt Brace College Publishers

Wardhaugh, Ronald. 1986. An Introduction to Sociolinguistics. New York: Basil Blackwell. Inc

Wolseley, Roland. E. 1972.

Understanding Magazines. Lowa State:

University Press.

www.answers.com/topic/advertising www.geocities.com/.../bilingualism.html,

2009

Yu- Chi- Hung. 1991. Code Mixing/ Code Switching. Retrieved on February 16, 2009 from www.google.com

Yusuf, A. Muri. 2007. Metodologi Penelitian. Padang. Universitas Negri Padang.

Yusrusyana. 1984. Perihal Kedwibahasaan (Bilingualisme). Jakarta: Departemen Pendidikan dan Kebudayaan. Direktorat Jendral Pendidikan Tinggi Proyek Pengembangan Lembaga Pendidikan Tenaga Pendidikan. 